\title{
The Effect of Programmed Instruction in Science Education on Students' Achievements and Attitudes
}

\section{Mustafa YILMAZLAR ${ }^{1, *}$, Alper ÇORAPÇIGİL ${ }^{1} \&$ Betül TOPLU}

\author{
${ }^{1}$ Sakarya University, Sakarya, TURKEY; ${ }^{2}$ Ministry of Education, Sakarya, \\ TURKEY
}

Received: 11.07 .2013

Accepted: 14.05 .2014

\begin{abstract}
The purpose of this study is to examine the impact of the method of programmed instruction in teaching science on student achievement and attitude. Pre-test and post-test control group experimental study was carried out in the pattern. The study group is 58 students attending primary school in the sixth grade. Fiveweek-long course is an experimental science and technology in the experimental group during the processing of transactions processed course the traditional method has been used with the programmed instruction. In the control group lecture, question-and-answer, and practice methods course taught by the application. Force and motion studies were performed to collect data validity and reliability of the achievement test and the attitude scale used in science and technology. Data analysis, independent samples t-test, ANCOVA and related samples t-test was used. Programmed instruction printed course material, used in conjunction with results of the study than the control group significantly enhances student achievement and attitudes. Time students in science teaching force and motion, and similar matters, and class / school environment, regardless of programmed teaching materials are developed and recommended for use.
\end{abstract}

Key words: Programmed instruction, printed material, science teaching

DOI No: 10.12973/nefmed.2014.8.1.a3

\section{Summary}

\section{Introduction}

According to constructivist approach be considered that be used programmed teaching method is effective on the structuring of knowledge cognitively (Toplu, Arslan, Okumuş, \&

\footnotetext{
* Corresponding author: Mustafa YILMAZLAR, Assoc. Prof. Dr. In Science Education, Faculty of Education, Sakarya University, Sakarya, TURKEY.

E-mail: myilmazlar@sakarya.edu.tr
} 
Akgün, 2007). Programmed teaching is one of the active learning methods. Programmed teaching is a method that the student participates actively in to learning, learning to make systematic progress in providing continuous control of the individual, self-learning method is defined and it can be applied on just to teaching a particular subject (Büyükkaragöz \& Çivi, 1999). Thus, in the past, put forward a teaching method in accordance with the use of the new teaching model can be ensured. Problem statement of this study on the basis of these statements "programmed instruction method of teaching science What is the impact on student achievement and attitude?", Respectively.

The aim and important of the study: Programmed instruction in science education studies that examine the impact on student achievement and attitude were found to be very limited. Therefore, considering the role and importance of science education in the training process was thought to be necessary to study the effects of this teaching method. Be learned and be kept in mind of a subject's programmed steps is easier than its written text information is kept in mind. Also, reading a printed material prepared that programmed steps is funny than reading a printed material prepared that plain text. Therefore, this study is important that with regard to the students can study independently of time and place and preparing programmed teaching materials to they can practice applications. Hence, this study was aimed to study the effects of programmed teaching method in science education on the achievement and attitude of students.

\section{Method:}

The study was conducted with experimental pattern with pretest-posttest experiment control group. In addition to the lesson, programmed teaching method was applied on the experiment group. Traditional teaching was used on control group. The study sample was 58 sixth grade students who are 24 girl 34 boy that studied in Sakarya in 2007-2008. Control group and experiment group consisted of 29 people. In the study, as tools to collect data the force and motion achievement test and the science and technology attitude scale were used. Before the starting the experimental applies the force and motion achievement and the science and technology attitude scale were applied as pretest to experiment and control group. The experiment processes were started after the pretests. The study was being applied during 20 lesson hours (5 weeks). While the experimental applies the programmed teaching materials were distributed to experiment group. The data were obtained at the study were analyzed with independent samples $t$ test and ANKOVA analysis. At the end of apply the achievement test and attitude scale as posttest were applied again. 


\section{Findings}

When the examine to the mean of posttest achievement scores of the students in experiment and control group, between achievement scores there is a significant difference in favor of experiment group $[\mathrm{t}(56)=3.113, \mathrm{p}<.05]$. Also when examine to their posttest attitude scores there is a significant difference between experiment and control group [ $\mathrm{t}(56)=3.843, \mathrm{p}<.05]$. Based on fixed posttest scores according to pretest score of the students in experiment and control group, there is a significant difference between achievement test mean scores. According to these findings, it is possible that experiment group is successfully than control group. When examine to fixed attitude posttest scores according to attitude pretest score, the students' attitude mean score who are in experiment group $\left(\mathrm{x}^{-}=64.335\right)$ is higher than control group's students' mean score $\left(\mathrm{x}^{-}=58.424\right)$. When the results of analysis are examined, the students' changes of pretest-posttest achievement who are in experiment $[\mathrm{t}(28)=15.09, \mathrm{p}<.05]$ and control $[\mathrm{t}(28)=8.981, \mathrm{p}<.05]$ group show significant difference in favor of posttest's scores. When the results of analysis are examined about attitude scores, there is a significant increase on the students' attitude scores which is toward to science and technology course that are in experiment group. Nevertheless, there is no difference in control group about it after traditional teaching $[\mathrm{t}(28)=.706, \mathrm{p}>.05]$.

\section{Result and Comment}

The programmed teaching which is applied as a support to science education increases significant the students' achievement than traditional teaching. In other words, it is possible to say that the programmed teaching is more effective than traditional teaching about students' achievement. Moreover, it can be said that the programmed teaching increases significant the students' attitude than traditional teaching. Therefore, it can be made inference that as should more care on the programmed teaching. 


\title{
Fen Bilgisi Öğretiminde Programlı Öğretimin Öğrenci Başarısı ve Tutumu Üzerindeki Etkisi
}

\author{
Mustafa YILMAZLAR ${ }^{1,}{ }^{*}$, Alper ÇORAPÇIGÍl ${ }^{1}$ \& Betül TOPLU ${ }^{2}$ \\ Sakarya Üniversitesi, Sakarya, TÜRKİYE; Milli Eğitim Bakanlığı, Sakarya, \\ TÜRKIYYE
}

Makale Gönderme Tarihi: 11.07.2013

Makale Kabul Tarihi: 14.05.2014

\begin{abstract}
Özet: Bu çalışmanın amacı fen öğretiminde programlı öğretim yönteminin öğrenci başarısı ve tutumu üzerindeki etkisini incelemektir. Araştırma ön test-son test deney kontrol gruplu deneysel desende yürütülmüştür. Çalışma grubunu ilköğretim altıncı sınıfta okuyan 58 öğrenci oluşturmaktadır. Beş hafta süren deneysel işlemler sırasında deney grubunda fen ve teknoloji dersinin işlenmesinde geleneksel işlenen dersle birlikte programlı öğretim yöntemi kullanılmıştır. Kontrol grubunda ise düz anlatım, soru-cevap ve alıştırma uygulama yöntemleriyle ders işlenilmiştir. Verilerin toplanmasında geçerlik ve güvenirlik çalışmaları yapılmış kuvvet ve hareket konusu başarı testi ve fen ve teknoloji tutum ölçeği kullanılmıştır. Verilerin analizinde ilişkisiz örneklemler $t$ testi, ANCOVA ve ilişkili örneklemler t-testi uygulanmıştır. Araştırma sonuçları dersle birlikte kullanılan programlı öğretim basılı materyalinin kontrol grubuna göre öğrenci başarısını ve tutumunu anlamlı olarak arttırdığını göstermektedir. Fen öğretiminde kuvvet ve hareket ve benzeri konularda öğrencilerin zamandan ve sinıf/okul ortamından bağımsız olarak kullanabilecekleri programlı öğretim materyallerinin geliştirilmesi ve kullanılması önerilmektedir.
\end{abstract}

Anahtar kelimeler: Programlı Öğretim, Basılı Materyal, Fen Bilgisi Öğretimi

DOI No: 10.12973/nefmed.2014.8.1.a3

\section{Giriş}

Fen bilimleri; doğa olaylarını sistematik bir şekilde inceleme ve henüz gözlenmemiş olayları kestirme gayretleridir. Doğanın her bir olayı fennin bir konusunu olduğu için, fen yaşamımızın önemli bir parçasıdır. Fen bilimleri canlı cansız ayrımı yapmadan bütün doğa ile ilgilenmekte olup, olgular, kavramlar ve genellemeler, ilkeler, kuramlar ve doğa yasalarından oluşmaktadır (Doğru ve Kıyıc1, 2005).

Fen öğretimindeki öğrenme yaşantıları ile öğrenciler bağımsız şekilde kendilerini yöneten insanlar olarak yetişirler. Öğrencileri problemleri tanıma, çözüm için plan yapma,

\footnotetext{
* İletişim: Doç. Dr. Mustafa YILMAZLAR, Fen Bilgisi Anabilim Dalı, Eğitim Fakültesi, Sakarya Üniversitesi, Sakarya, TÜRKIYE.

E-posta: myilmazlar@sakarya.edu.tr
} 
veri toplama, karar verme, bu karara göre eyleme geçme ve en sonunda ürünleri değerlendirme becerileri ile donatmak fen öğretimiyle olanaklıdır. Fen öğretimi ile öğrenciler gelecekte pek çok iş için gerekli olacak problem çözme, yaratıcılık, analiz etme, sentez yapma, eleştirici düşünme, elde edilen bilgiyi güncel sorunlara uygulama gücü kazanmaktadır (Fidan ve Baykul, 1993).

Fen eğitimi, temelde bilimsel düşüncenin oluşturulmasına, sorunlara mantıklı yaklaşılmasına ve bilimin günlük hayattaki öneminin kavranmasına yardımcıdır (Çilenti, 1985). Fen eğitiminde bireyler bilimsel bilgileri, bilimsel süreç becerileri ve bilimsel tutumları kazanmaya başlarlar. Bu nedenle, fen eğitimi bireyin gelecekteki yaşamını yönlendirme açısından oldukça önemli bir yere sahiptir. Araştıran, tartışan, bilimsel süreç becerilerini kullanabilen, bilime karşı olumlu tutumlar sergileyen fen okuryazarı bireylerin yetiştirilmesinde fen eğitimi önem kazanır (Çepni, Ayvacı ve Bacanak, 2004).

Geleneksel öğretimin yapıldığı sınıf öğretimi kendi yapısında birçok sorunu birlikte taşır. Öğrenme hızı değişik olan öğrencilere ayrı ayrı pekiştireç vermek çok zordur. Sınıfta öğrencilerin istenilen her davranışı yapma olanağı sınırlıdır. Çoğu zaman pekiştirme gecikmeli olarak yapılabilmektedir (Kurbanoğlu, 2002).

Geleneksel yöntemlerin tatmin edici olmayan sonuçları, ders kitabı, öğretmen, tebeşirden oluşan eğitim ortamı ya da yazı tahtası, bireylere kazandırılacak bilgi ve becerilerin hızla artması ve eğitim sisteminde bulunan birey sayısı, eğitimcileri yeni olanaklar aramaya ve onları farklı projeler üretmeye yöneltmektedir. Şu anda ilköğretim okullarında uygulanmakta olan yapılandırmacı öğretim modeli de bu arayışlar sonucunda ortaya çıkmıştır. Yapılandırmacı anlayışa göre bilginin bilişsel olarak yapılandırılmasında programlı öğretim yönteminin kullanılmasının etkili olacağı düşünülmüştür (Toplu ve diğerleri, 2007). Programlı öğretim, öğretilecek konunun olanaklar ölçüsünde, her birinde özel bir fikir veya görüş bulunan, küçük ünitelere ayrılıp, bu ünitelerin belirli bir düzene konulduğu, her ünitedeki bilginin öğrenilip öğrenilmediğini kontrol etme olanağının bulunduğu bireysel, kendi kendine öğrenme yöntemidir (Küçükahmet, 1997a). Programlı öğretim aktif öğrenme yöntemlerinden biridir. Bireyi merkeze alarak öğrencilerin özelliklerine göre öğretimi esnekleştirebilen ve öğrencilerin kendi hızları doğrultusunda ilerlemelerine firsat veren; ayrıca öğrencilerin kendilerini değerlendirebilecekleri bireysel bir öğrenme programıdır. Literatürde programlı öğretime ilişkin birçok tanım bulunmaktadır. Bunlardan bir kısmı şu şekilde verilebilir: 
Programlı öğretim; bir öğrencinin davranışsal amaçları kazanmasına yardım etmek için deneysel olarak geliştirilmiş öğrenme tekniklerinin sistematik olarak uygulanmasıyla desenlenmiş bir süreçtir (Alkan, 1977).

Programlı öğretim yöntemi, öğrenme süreci boyunca her öğrencinin bireysel özelliklerini göz önünde bulundurarak, öğretmenin direkt müdahalesine gerek kalmaksızın öğrencinin kendi kendine öğrenmesine imkân veren bir yöntemdir (Hızal, 1982).

Programlı öğretim; öğrenilecek muhtevanın olanaklar ölçüsünde, her birinde özel bir fikir veya görüş bulunan, küçük ünitelere ayrılıp, bu ünitelerin sıraya göre düzene konulduğu, her ünitedeki bilginin öğrenilip öğrenilmediğini kontrol etme olanağının bulunduğu bireysel, kendi kendine öğrenme yöntemidir (Küçükahmet, 1997a).

Programlı öğretim öğrencinin öğrenme sürecinde sistemli bir ilerleme yapmasını, öğrenmeye aktif olarak katılımını ve öğrenmenin sürekli kontrol edilmesini sağlayan kendi kendine öğrenme yöntemi olarak tanımlanmakta olup bir okulda okutulan sadece belirli bir konunun öğretilmesi için uygulanabilecek bir öğretim planlaması ve yürütülmesi yöntemidir (Büyükkaragöz ve Çivi, 1999).

Böylece geçmişte ortaya atılmış bir öğretim yönteminin yeni öğretim modeli içinde uygun bir şekilde kullanılması sağlanmış olur. Bu araştırmada söz konusu açıklamalardan yola çıkılarak problem cümlesi "Fen öğretiminde programlı öğretim yönteminin öğrenci başarısı ve tutumu üzerindeki etkisi nedir?" şeklinde belirlenmiştir.

Fen öğretiminin eğitim sürecindeki yeri ve önemi düşünüldüğünde bu öğretim yönteminin etkilerinin araştırılarak önceden yapılan çalışmalara katkıda bulunulmasının gerekli olduğu düşünülmüştür.

Deneysel nitelikteki bu araştırma, programlı öğretim yönteminin ülkemizde fen öğretiminde kullanılıp kullanılmayacağını göstermesi bakımından önemlidir. Bu araştırmanın sonuçlarının ve önerilerinin ülkemizde daha etkin ve verimli bir fen öğretiminin oluşturulmasına katkıda bulunacağı umulmaktadır.

$\mathrm{Bu}$ araştırmanın programlı öğretim uygulaması yapacak eğitim kuruluşlarına ve öğretmenlere yol gösterici niteliği taşıması beklenmektedir. Ayrıca programlı öğretim yöntemine ilişkin olarak yapılacak araştırmalarda, araştırmacılara 1şık tutacağı umulmaktadır.

Özellikle ülkemiz koşulları düşünüldüğünde öğrencilerin en çok zorlandıkları, anlamakta güçlük çektikleri ve başarısız oldukları derslerin başında fen dersleri geldiği için programlı öğretim yöntemi bu soruna bir alternatif çözüm olabilir. Bunun yanında programlı 
öğretimin eğitim sistemine getireceği katkıların ve öğrenmede sunduğu olanaklar ile eğitimde öğrencilerin başarılarına ve derse yönelik tutumlarına etkisinin değerlendirilmesi ve uygulanabilirliğin araştırılması önem taşımaktadır. Ayrıca bu araştırma zaman sınırlamasını ortadan kaldırdığı, öğrenmede bireysellik sağladığı ve kendi kendine öğrenmeye olanak tanıdığı, bilgilerin küçük adımlarla sistemli bir biçimde verildiği ve kolay öğrenme sağladığ1 için dışarıdan okulları bitirecek bireylere programlı öğretim materyallerinin sunulmasıyla ilgili fikirlerin gelişmesine de katkıda bulunabilir.

Bir konunun programlı basamaklarının öğrenilip akılda tutulması yazılı metin bilgisinin öğrenilip akılda tutulmasına kıyasla daha kolaydır. Ayrıca programlı basamaklar halinde düzenlenmiş bir basılı materyali okumak düz metin halinde düzenlenmiş bir basılı materyali okumaktan daha eğlencelidir. Bu sebeple bu araştırma öğrencilerin zamandan ve mekândan bağımsız olarak çalışabilecekleri, alıştırma uygulama yapabilecekleri programlı öğretim materyallerinin hazırlanması fikrine 1şık tutması açısından önemlidir.

Aşağıda programlı öğretim ile ilgili yapılan bazı çalışmalar ve sonuçlarına yer verilmiştir.

Kurbanoğlu 2002'de organik kimyada stereo kimya konusunun programlı öğretimi üzerine bir çalışma yapmıştır. Kurbanoğlu Atatürk Üniversitesi Kazım Karabekir Eğitim Fakültesi Kimya Eğitimi Anabilim Dalı 2. sınıfta okuyan 410 öğrenci üzerinde yaptığ1 çalışmada programlı öğretim yönteminin ve geleneksel öğretim yönteminin stereo kimya konusu ile ilgili kavram ve kuralların öğrenilmesindeki etkinliğini araştırmıştır. Ayrıca uygulanan programlı öğretim yönteminin öğrencilerin organik kimyaya karşı tutumları üzerindeki etkisini incelemiştir. 4 hafta süren çalışma sonucunda organik kimyada stereo kimya konusunun öğretimi üzerine programlı öğretim yönteminin kullanıldığı deney grubu öğrencilerinin, geleneksel öğretim yönteminin kullanıldığı kontrol grubu öğrencilerinden anlamlı olarak daha başarılı olduğunu bulmuştur. Ayrıca programlı öğretim yönteminin öğrencilerin organik kimyaya karşı tutumları üzerinde olumlu bir etkisinin olduğunu tespit etmiştir.

Toplu ve arkadaşları, 2007'de programlı öğretim uygulamalarının ilköğretim 7. sınıf öğrencilerinin fen bilgisi dersi başarı ve tutumları üzerindeki etkisini incelemişlerdir. Araştırma ön test-son test deney kontrol gruplu deneysel desende yürütülmüştür. Çalışma grubunu ilköğretim yedinci sınıfta okuyan 99 öğrenci oluşturmaktadır. Araştırmacılar iki hafta süren deneysel işlemler sırasında deney 1 grubunda fen bilgisi dersinin işlenmesinde sadece programlı öğretim yöntemi, deney 2 grubunda geleneksel işlenen dersle birlikte programlı 
öğretim yöntemi kullanmışlardır. Kontrol grubunda ise düz anlatım, soru-yanıt ve alıştırma uygulama yöntemleriyle ders işlemişlerdir. Araştırma sonucunda basılı materyal biçiminde derse destek olarak uygulanan programlı öğretimin hem sadece programlı öğretim (yani sadece programlı öğretimin öğretim yöntemi olarak kullanıldığı) hem de geleneksel (yani düz anlatım, soru-cevap ve alıştırma uygulama yöntemlerinin kullanıldığı) öğretime göre öğrenci başarısını anlamlı olarak artırdığını bulmuşlardır. Ayrıca araştırmacılar deneysel işlemler sonrasında deney ve kontrol gruplarının tutumları arasında anlamlı bir farklılık bulamamışlardır.

Amaç

$\mathrm{Bu}$ araştırmanın amacı fen öğretiminde programlı öğretim yönteminin öğrenci başarısı ve tutumu üzerindeki etkisini incelemektir. Bu kapsamda aşağıdaki sorulara cevap aranmaktadır.

1. Derse destek biçiminde programlı öğretimin uygulandığg deney grubundaki öğrencilerin ve geleneksel öğretimin uygulandığı kontrol grubundaki öğrencilerin ön test puan ortalamaları arasında anlamlı bir farklılık var mıdır?

2. Derse destek biçiminde programlı öğretimin uygulandığı deney grubundaki öğrencilerin ve geleneksel öğretimin uygulandığg kontrol grubundaki öğrencilerin son test puan ortalamaları arasında anlamlı bir farklılık var midır?

3. Deney ve kontrol gruplarındaki öğrencilerin ön test puanlarına göre düzeltilmiş son test puanları temel alındığında, başarı testi ortalama puanları arasında anlamlı bir farklılık var midir?

4. Deney ve kontrol gruplarındaki öğrencilerin başarı ve tutum ön test puanlarına göre düzeltilmiş son test puanları temel alındığında, başarı testi ortalama puanları arasında anlamlı bir farklılık var midır?

5. Deney ve kontrol gruplarındaki öğrencilerin ön test puanlarına göre düzeltilmiş son test puanları temel alındığında, tutum ölçeği ortalama puanları arasında anlamlı bir farklılık var mıdır?

\section{Yöntem}

$\mathrm{Bu}$ araştırma ön test-son test kontrol gruplu deneysel desende yürütülmüştür. Araştırmanın bağımlı değişkenleri fen ve teknoloji dersi kuvvet ve hareket konusuyla ilgili başarı ve fen ve teknoloji dersine yönelik tutumdur. Araştırmanın bağımsız değişkeni ise 
kullanılan öğretim yöntemidir. Öğretim yönteminin deney ve kontrol olmak üzere iki düzeyi vardır. Deney grubunda öğretmenin işlediği derse ek olarak programlı öğretim yöntemi uygulanmıştır. Deney grubunda öğretmen haftada 4 saat olan fen ve teknoloji dersinin ilk saatinde öğrencilerin alıştıkları öğrenme kültürüne uygun olarak düz anlatım, soru-cevap, alıştırma uygulama yöntemlerini kullanarak dersi işlemiş ikinci saatinde de öğrencilerin programlı öğretim materyallerine çalışmalarına olanak sağlamıştır. Kontrol grubunda ise geleneksel öğretim kullanılmıştır. Bunun sebebi 2005 yılında ülkemizde uygulamaya konulan yapılandırmacı öğretimin henüz geçiş aşamasında olmasıdır. Bu aşamada geleneksel öğretim bir anda silinip atılamayacağı için kontrol grubunda geleneksel öğretim kullanılmıştır. Geleneksel öğretimde düz anlatım, soru cevap ve alıştırma-uygulama yöntemleri kullanılmıştır. Programlı öğretim materyallerinin uygulanması dışında deney grubunda ve kontrol grubunda geleneksel bir yaklaşım izlenmesinin sebebi yeni program gereği uygulanan öğretim etkinliklerinin araştırmanın sonucunu etkileyeceğidir.

Tablo 1. Deney Deseni

\begin{tabular}{|c|c|c|c|}
\hline Grup & Ön Test & Uygulama & \\
\hline \multirow[t]{3}{*}{ Deney } & Başarı Testi & $\begin{array}{lr}\text { Programlı } & \text { Öğretim } \\
\text { Yöntemi (derse destek } \\
\text { biçiminde uygulanmıştır). }\end{array}$ & Başarı Testi \\
\hline & Tutum Ölçeği & & Tutum Ölçeği \\
\hline & Başarı Testi & Geleneksel & Başarı Testi \\
\hline Kontrol & Tutum Ölçeği & $\begin{array}{l}\text { Yöntemi (soru-cevap, düz } \\
\text { anlatım, } \\
\text { uygulama). }\end{array}$ & Tutum Ölçeği \\
\hline
\end{tabular}

a-Örneklem

Araştırmanın örneklemini 2007-2008 eğitim-öğretim yılı Sakarya ilindeki bir ilköğretim okulunda okuyan 24 kız, 34 erkek olmak üzere toplam 58 altıncı sınıf öğrencisi, oluşturmaktadır. Araştırmaya katılan 58 öğrencinin 29’u deney, 29’u kontrol grubunu oluşturmaktadır. Deney ve kontrol grupları rastgele atanmıştır.

\section{b-Veri Toplama Araçları}

Araştırmada kullanılan veri toplama araçları kuvvet ve hareket başarı testi ile fen ve teknoloji tutum ölçeğidir. 
Kuvvet ve hareket başarı testi araştırmacı tarafindan geliştirilmiştir. Başarı testi hazırlanmadan önce ilk olarak kuvvet ve hareket konusunun kazanımları belirlenmiştir. Kazanımlar, 2007-2008 öğretim yılı fen ve teknoloji dersi 6. sınıf öğretim programındaki kuvvet ve hareket ünitesinin kazanımları dahilinde belirlenmiştir.

Kazanımlar belirlendikten sonra 59 maddeden oluşan kuvvet ve hareket başarı testi oluşturulmuştur. Oluşturulan kuvvet ve hareket başarı testi bilgilerin doğruluğu ve kazanımlara uygunluğu açısından 3 tane fen ve teknoloji öğretmeni, 1 tane fen bilgisi öğretimiyle ilgili öğretim üyesi tarafından incelenmiştir. Dil bilgisine uygunluğu açısından da 2 tane Türkçe öğretmeni tarafından incelenmiştir. Uzman görüşü alındıktan sonra test formunun ön uygulaması 2007-2008 öğretim yılı birinci döneminde bir ilköğretim okulunda öğrenim gören 79 yedinci sınıf öğrencisi üzerinde gerçekleştirilmiştir. Ön uygulama sonrasında ayırt ediciliği ve güvenilirliği düşük olan 18 madde alan uzmanının da tavsiyesiyle testten çıkarılmıştır. 41 maddeden oluşan kuvvet ve hareket başarı testinin alfa güvenirlik katsayısı ITEMANN programı kullanılarak 0.91 olarak bulunmuştur.

Test maddeleri çoktan seçmeli maddeler halinde yazılmıştır. Her çoktan seçmeli madde, bir madde kökünden, üçü çeldirici biri doğru cevap olmak üzere 4 seçenekten oluşmuştur. Her doğru cevaba 1 puan verilerek puanlama yapılmıştır.

\section{d-Fen ve Teknoloji Tutum Ölçeği}

Fen ve teknoloji tutum ölçeği, Geban ve arkadaşları (1994) tarafından "Fen Bilgisi Tutum Ölçeği” olarak geliştirilmiştir.

Tutum ölçeği öğrencilerin fen ve teknoloji dersine karşı tutumlarına yönelik olumlu ve olumsuz yargılar içeren 15 cümleden oluşmaktadır. Olumlu cümleler için verilen cevaplar "tamamen katılıyorum=5", "katılıyorum=4", "kararsızım=3", "katılmıyorum=2", "hiç katılmıyorum=1" olarak puanlanmıştır. Olumsuz cümleler için verilen cevaplar ise, "tamamen katılıyorum=1", katılıyorum=2", "kararsızım=3", "katılmıyorum=4", "hiç katılmıyorum=1 olarak puanlanmıştır.

\section{e- Programlı Öğretim Materyalinin Hazırlanması}

Programlı öğretim materyalinin hazırlanması 1) hazırlık, 2) yazma, 3) deneme olmak üzere, üç aşamada gerçekleştirilir (Alkan, 1977; Küçükahmet, 1997b; Hızal, 1978). Bu araştırmada kullanılan programlı öğretim materyalinin hazırlanmasında bu ilkeye uyulmuştur. Aşağıda her aşamada gerçekleştirilen etkinlikler açıklanmıştır.

el-Hazırlık 
Hazırlık aşamasında ilk olarak kuvvet ve hareket konusunun programlanmasına karar verilmiştir. Kuvvet ve hareket konusu fen ve teknoloji dersinin en önemli parçalarıdır. Çünkü kuvvet ve hareket konusu diğer bazı fen konularını anlayabilmek için ve ileriki öğretim kademelerinde öğrencilerin sıkıntı çekmemeleri için gerekli olan ön bilgileri içermektedir. Ayrıca araştırmanın yapılacağı okulda görevli bütün fen ve teknoloji öğretmenleri ile yapılan görüşmede, öğretmen öğrencilerin kuvvet ve hareket ünitesini öğrenmede güçlük çektiklerini belirtmiştir. $\mathrm{Bu}$ sebeple bu konuda öğrencilerin programlı öğretim materyaliyle çalışma yapmaları onların kuvvet ve hareket konularını anlamalarını ve ileriki öğretim kademelerinde sorun yasamamalarını sağlayacaktır. Programlanacak konunun seçiminde kuvvet ve hareket konusunun öneminin dikkate alınmasının yanı sıra bu konunun programlamaya uygun olması ve daha çok alıştırma yapmayı, problem çözmeyi gerektirmesi de dikkate alınmıştır. Kuvvet ve hareket konusunun programlanmasına karar verildikten sonra ünitenin kazanımları mevcut kazanımlar arasından belirlenmiştir. Kazanımlar belirlendikten sonra materyalin gerçekleştirilmesinde doğrusal program modeli benimsenmiştir. Ancak, doğrusal program modelinin, hızlı ve yavaş öğrenmekte olan öğrencilere karsı olumsuz yönlerinden dolayı geri dönme ve ileri gitme mekanizmasıyla birleştirilerek hazırlanmasına karar verilmiştir. Ayrıca geleneksel öğretim yöntemine alışmış öğrencilerin, değişik bir öğretim yöntemi olarak programlı öğretim ile karsılaştıklarında doğrusal program modeline daha rahat uyum sağlayacağı düşünülmüş ve programlı materyalin doğrusal program modeline göre hazırlanmasına karar verilmiştir.

\section{e2- Yazma}

Programlı öğretim materyalinin hazırlanmasında ikinci asama yazma aşamasıdır. Bu aşamada maddelerin yazımı gerçekleştirilir. Programlı materyali yazma aşamasına ilk olarak programlı materyalin nasıl kullanılacağına ilişkin bir açıklama yazısının yazılmasıyla başlanmıştır. Daha sonra maddelerin yazımına geçilmiştir. Programlı materyalde içerik ekran adı verilen maddeler halinde sunulmuştur. Programlı materyal toplam 159 maddeden (ekrandan) oluşmaktadır. Her bir ekranda bilgi ünitesi, örnek veya soru bulunmaktadır. Materyalin sol kısmında da cevaplar ve cevaplara ilişkin yönergeler yer almaktadır. Öğrenci ilk olarak ekranda verilen bilgi ünitesini okumakta daha sonra diğer ekrandaki örneklere geçmektedir. Bilgi ünitesi ve örnekler ekranını geçtikten sonra sorunun bulunduğu ekrana geçerek soruyu cevaplamaktadır. Soruyu cevaplamadan önce ise sol taraftaki cevaplar sütununu kendisine verilen karton ile kapatmaktadır. Soruyu cevapladıktan sonra cevaplar bölümünü açarak cevabını kontrol etmektedir. Eğer cevabı doğruysa burada kendisine verilen 
yönerge ile bir sonraki ekranlara geçmekte, eğer cevabı yanlış ise kendisine verilen yönerge ile sorunun çözümünün olduğu ekrana veya konunun anlatıldığı ekrana tekrar geri dönmektedir. Programlı öğretim materyali yukarıda anlatılan şekilde yazıldıktan sonra alan uzmanının incelemesine sunulmuştur. Hazırlanan programlı öğretim materyali konuyla ilgili bir öğretim üyesi ve 4 fen ve teknoloji öğretmeni tarafindan incelenmiştir. Öğretim üyesi ve fen ve teknoloji öğretmenleri materyali bilgilerin doğruluğu, kazanımlara uygunluğu ve bilgilerin veriliş sırası bakımından incelemişlerdir. Programlı öğretim materyali görsel tasarım açısından ve programlı öğretim yönteminin ilkelerine uygunluğu açısından da bir öğretim üyesi ve bir teknoloji ve tasarım öğretmeni tarafından incelenmiştir. Programlı öğretim materyali anlatım dilinin uygunluğu bakımından ise bir Türkçe öğretmeni tarafından incelenmiştir. Uzmanların görüşleri alındıktan sonra programlı öğretim materyalinde gerekli düzeltmeler yapılmıştır ve ilk taslak oluşturulmuştur.

\section{e3-Deneme}

Programlı öğretim materyalinin hazırlanmasında üçüncü asama deneme aşamasıdır. Bu aşamada programlı öğretim materyali deney ve kontrol grubu dışındaki öğrenciler üzerinde denenmiştir. Programlı öğretim materyali 3'ü kız, 2'si erkek olmak üzere kuvvet ve hareket konusunu daha önce hiç öğrenmemiş toplam 5 altıncı sınıf, 3'ü kız, 3'ü erkek olmak üzere kuvvet ve hareket konusunu daha önce öğrenmiş toplam 6 yedinci sınıf öğrencisi üzerinde denenmiştir. Deneme sırasında öğrencilerden programlı materyale çalışmaları ve anlamadıkları yerleri söylemeleri istenmiştir. Ayrıca programlı materyal hakkındaki görüşleri alınmıştır. Öğrencilerin görüşleri alındıktan sonra gerekli düzeltmeler yapılmıştır. Programlı öğretim materyalinin basılı materyal biçiminde sunulmasına karar verilmiştir. Daha sonra materyal fotokopi yoluyla çoğaltılarak uygulamaya hazır hale getirilmiştir.

\section{f- Uygulama}

Deneysel işlemlerin uygulaması 2007-2008 öğretim yılında bir ilköğretim okulunda okuyan 58 öğrenci üzeride yapılmıştır. Deneysel işlemlere başlamadan önce deney ve kontrol grubundaki öğrencilere kuvvet ve hareket basarı testi ile fen ve teknoloji tutum ölçeği ön test olarak uygulanmıştır. Deney ve kontrol gruplarına ön testler uygulandıktan sonra uygulamaya başlanmıştır. Uygulama toplam 20 ders saati (5 hafta) boyunca uygulanmıştır. Deneysel işlemler sırasında deney grubuna programlı öğretim materyalleri dağıtılmıştır. Öğrencilere programlı öğretim materyallerini nasıl kullanmaları gerektiği hakkında bilgi verilmiştir. Deneysel işlemler sırasında deney grubunda öğretmen öğrencilerin alıştıkları öğrenme kültürüne uygun olarak düz anlatım, soru cevap, alıştırma uygulama yöntemlerini kullanarak 
dersi islemiş daha sonra da öğrencilerin programlı öğretim materyallerine çalışmalarına olanak sağlamıştır. Yani deney grubundaki öğrenciler programlı öğretim materyallerini öğretmenin islediği derse destek biçiminde kullanmışlardır. Programlı öğretim basılı materyaller kullanılarak islenmiştir. Araştırmada kullanılan programlı öğretim basılı materyallerin bir örneği EK-1 de verilmiştir. Kontrol grubunda ise herhangi bir yeni işlem uygulanmamış, öğrencilerin alıştıkları öğrenme kültürüne uygun olarak düz anlatım, sorucevap, alıştırma uygulama yöntemleri kullanılarak ders islemiştir. Deneysel işlemlerin bitmesinin ardından kuvvet ve hareket basarı testi ile fen ve teknoloji tutum ölçeği son test olarak uygulanmıştır.

g-Verilerin Toplanması

Deneysel işlemlerin uygulaması 2007-2008 öğretim yılında bir ilköğretim okulunda okuyan 58 öğrenci üzerinde yapılmıştır. Deneysel işlemlere başlamadan önce deney ve kontrol grubundaki öğrencilere kuvvet ve hareket başarı testi ile fen ve teknoloji tutum ölçeği ön test olarak uygulanmıştır. Deney ve kontrol gruplarına ön testler uygulandıktan sonra uygulamaya başlanmıştır. Uygulama toplam 20 ders saati (5 hafta) boyunca uygulanmıştır.

\section{h-Verilerin Analizi}

Araştırmada ölçme araçlarından elde edilen verilerin analiz edilmesinde SPSS for Windows 11.5 paket programı kullanılmıştır. Verilerin analiz edilmesinde deney ve kontrol gruplarının ön test ve son test başarılarını ve tutumlarını karşılaştırmak amacıyla ilişsisiz örneklemler $\mathrm{t}$ testi kullanılmıştır (Büyüköztürk, 2004). Daha sonra deney ve kontrol gruplarının başarılarını ve tutumlarını karşılaştırmak amacıyla öğrencilerin ön test puanlarına göre son test puanlarını yeniden hesaplayarak inceleyen ANCOVA analizi kullanılmıştır. Deney ve kontrol gruplarının kendi içlerinde ön test-son test puan değişimlerini incelemek amacıyla ise ilişkili örneklemler t testi kullanılmıştır.

\section{Bulgular}

Araştırma sonucunda elde edilen verilere yönelik bulgular aşağıda açıklanmaya çalışılmıştır.

Deney ve kontrol gruplarının başarı ve tutum son test puanlarının ilişkisiz örneklemler için t testi sonuçları Tablo 2' de sunulmuştur. Deney ve kontrol gruplarındaki öğrencilerin son test başarı puan ortalamalarına bakıldığında, başarı puanları arasında deney grubunun lehine anlamlı bir farklılık bulunmaktadır $[\mathrm{t}(56)=3.113, \mathrm{p}<.05]$. 
Tablo 2. Deney ve Kontrol Gruplarının Başarı ve Tutum Son Test Puanlarının İlişkisiz Örneklemler t Testi Sonuçları

\begin{tabular}{llllllll}
\hline & Grup & N & Ortalama & S & sd & t & p \\
\hline Başarı & Deney & 29 & 31.20 & 4.77 & 56 & 3.113 & .003 \\
Son test & Kontrol & 29 & 25.24 & 9.14 & & & \\
Tutum & Deney & 29 & 65.27 & 5.73 & & & \\
Son test & Kontrol & 29 & 57.48 & 9.29 & 56 & 3.843 & .000 \\
& & & & & & \\
\hline
\end{tabular}

$\mathrm{Bu}$ bulgu, derse destek biçiminde programlı öğretimin kullanıldı̆̆ öğrencilerin başarısı, geleneksel öğretim yöntemlerinin kullanıldığı kontrol grubundaki öğrencilerin başarısından anlamlı olarak daha yüksektir şeklinde yorumlanabilir.

Deney ve kontrol gruplarındaki öğrencilerin son test tutum puan ortalamalarına bakıldığında, deney ve kontrol grupları arasında anlamlı bir farklılık bulunmaktadır [ $\mathrm{t}(56)=$ 3.843, $\mathrm{p}<.05]$. Bu bulgu, derse destek biçiminde programlı öğretimin kullanıldığı deney grubundaki öğrencilerin tutumları, geleneksel öğretim yöntemlerinin kullanıldığı kontrol grubundaki öğrencilerin tutumlarından anlamlı olarak daha yüksektir şeklinde yorumlanabilir.

Deney ve kontrol gruplarının ön test başarı puan ortalamaları arasında anlamlı bir farklılık görülmemektedir. Ancak deney grubundaki öğrencilerin ön test başarı ortalamaları ( $\bar{X}=17.51)$, kontrol grubundaki öğrencilerin ön test başarı ortalamalarından $(\bar{X}=16.55)$ anlamlı bir farklılık olmamasına rağmen daha yüksektir. Deney ve kontrol gruplarının ön test başarı puan ortalamaları arasındaki farklılığ düzeltmek amacı ile ANCOVA analizi kullanılmıştır. ANCOVA analizi başlangıçta öğrencilerin ön test puan ortalamaları eşit olsa dahi kullanılabilecek güçlü bir istatistiktir (Büyüköztürk, 2004). ANCOVA analizi ile öğrencilerin ön test puanlarına göre son test puanlarını yeniden hesaplanarak analiz sonuçları incelenir. Buna göre başarı ön test puanlarına göre düzeltilmiş başarı son test puanlarının gruba göre ANCOVA sonuçları Tablo 3'de kuvvet ve hareket başarı testi betimsel istatistikleri Tablo 4'de verilmiştir. 
Tablo 3. Başarı Testi Puanlarının ANCOVA Sonuçları

\begin{tabular}{llllll}
\hline $\begin{array}{l}\text { Varyansın } \\
\text { Kaynağı }\end{array}$ & Kareler Toplamı & sd & $\begin{array}{l}\text { Kareler } \\
\text { Ortalaması }\end{array}$ & $\mathbf{F}$ & $\mathbf{p}$ \\
\hline Ön Test reg. & 1618.938 & 1 & 1618.938 & 65.321 & .000 \\
Grup & 384.066 & 1 & 384.066 & 15.496 & .000 \\
Hata & 1363.131 & 55 & 24.784 & & \\
Toplam & 49701.000 & 58 & & & \\
\hline
\end{tabular}

Tablo 4. Başarı Testi Puanlarının Betimsel İstatistikleri

\begin{tabular}{llll}
\hline \multirow{3}{*}{ Grup } & $\mathbf{N}$ & \multicolumn{2}{l}{ Başarı-son test } \\
\cline { 3 - 4 } & & Ortalama & Düzeltilmiş Ortalama \\
\hline Deney & & & \\
\hline Kontrol & 29 & 31.2069 & 30.805 \\
\hline
\end{tabular}

Tablo 3'deki analiz sonuçları incelendiğinde, deney ve kontrol grupları arasında deney grubu lehine anlamlı bir farklılık olduğu görülmektedir $[F(1)=15.496, p<.05]$. Tablo 4'deki ön test puanlarına göre düzeltilmiş son test puanları incelendiğinde de deney grubundaki öğrencilerin başarı ortalamasının $(\bar{X}=30.805)$ kontrol grubundaki öğrencilerin başarı ortalamasına göre $(\bar{X}=25.643)$ daha yüksek olduğu görülmektedir. Bu bulgular deney grubundaki öğrencilerin kontrol grubundaki öğrencilere göre daha başarılı olduğu şeklinde yorumlanabilir.

Deney ve kontrol gruplarındaki öğrencilerin ön test puanlarına göre düzeltilmiş son test puanları temel alındığında, başarı testi ortalama puanları arasında anlamlı bir farklılık vardır. $\mathrm{Bu}$ bulgulara göre, deney grubunun kontrol grubundan daha başarılı olduğunu söylemek mümkündür. Ancak deney grubundaki öğrencilerin tutum ön test puan ortalamalarının kontrol grubundaki öğrencilerin tutum ön test puan ortalamalarından daha yüksek olması, deney ve kontrol gruplarındaki başarı testi ortalama puanları arasındaki farkın, öğrencilerin yüksek tutumlarından ileri gelebileceğini düşündürebilir. Bu sebeple deney grubunun başarı ön test 
ve tutum ön test puanlarındaki farklılığı düzeltmek amacıyla öğrencilerin başarı ve tutum ön test puanlarına göre başarı son test puanları ANCOVA analizi ile tekrar hesaplanmıştır. Başarı ve tutum ön test puanlarına göre düzeltilmiş, başarı son test puanları arasında gruplara göre anlamlı bir farklılık olup olmadığına bakılmıştır. Buna göre, başarı ve tutum ön test puanlarına göre düzeltilmiş başarı son test puanlarının gruba göre ANCOVA sonuçları Tablo 5'de, başarı ve tutum ön test puanlarına göre düzeltilmiş başarı ortalamaları Tablo 6'da verilmiştir.

Tablo 5. Başarı ve Tutum Ön Test Puanlarına Göre Düzeltilmiş Başarı Son Test Puanlarının Gruba Göre ANCOVA Sonuçları

\begin{tabular}{llllll}
\hline Varyansın Kaynağı & $\begin{array}{l}\text { Kareler } \\
\text { Toplamı }\end{array}$ & sd & $\begin{array}{l}\text { Kareler } \\
\text { Ortalaması }\end{array}$ & F & p \\
\hline Başarı Ön Test reg. & 1234.130 & 1 & 1234.130 & 50.473 & .000 \\
Tutum Ön Test reg & 42.774 & 1 & 42.774 & 1.749 & .192 \\
Grup & 326.337 & 1 & 326.337 & 13.347 & .001 \\
Hata & 1320.357 & 54 & 24.451 & & \\
Toplam & 49701.000 & 58 & & & \\
\hline
\end{tabular}

Tablo 6. Başarı ve Tutum Ön Test Puanlarına Göre Düzeltilmiş Başarı Ortalamaları

\begin{tabular}{llll}
\hline \multirow{3}{*}{ Grup } & $\mathbf{N}$ & \multicolumn{2}{c}{ Başarı-son test } \\
\cline { 3 - 4 } & & Ortalama & $\begin{array}{l}\text { Düzeltilmiş } \\
\text { Ortalama }\end{array}$ \\
\hline Deney & 29 & 31.2069 & 30.644 \\
Kontrol & 29 & 25.2414 & 25.804 \\
\hline
\end{tabular}

Tablo 5'deki analiz sonuçları incelendiğinde, gruplar arasında anlamlı bir farklılık olduğu görülmektedir $[\mathrm{F}(1)=13.347, \mathrm{p}<.05]$. Tablo 6'daki başarı ve tutum ön test puanlarına göre düzeltilmiş başarı son test puanları incelendiğinde de deney grubundaki öğrencilerin başarı puanlarının ortalamasının $(\bar{X}=30.644)$, kontrol grubundaki öğrencilerin başarı 
puanlarının ortalamasına göre $(\bar{X}=25.804)$ daha yüksek olduğu görülmektedir. Bu bulgular deney grubundaki öğrencilerin kontrol grubundaki öğrencilere göre daha başarılı olduğu şeklinde yorumlanabilir.

Deney ve kontrol gruplarının ön test tutum puan ortalamaları arasında anlamlı bir farklılık görülmemektedir. Ancak deney grubundaki öğrencilerin ön test tutum ortalamaları ( $\bar{X}=62.10)$, kontrol grubundaki öğrencilerin ön test tutum ortalamalarından $(\bar{X}=58.65)$ anlamlı bir farklılık olmamasına rağmen daha yüksektir. Deney ve kontrol gruplarının ön test tutum puan ortalamaları arasındaki farklılığı düzeltmek amacı ile ANCOVA analizi kullanılmıştır. Buna göre tutum ön test puanlarına göre düzeltilmiş tutum son test puanlarının gruba göre ANCOVA sonuçları Tablo 7'de ve fen ve teknoloji tutum ölçeği puanlarının betimsel istatistikleri Tablo 8'de verilmiştir.

Tablo 7. Fen ve Teknoloji Tutum Ölçeği Puanlarının ANCOVA Sonuçları

\begin{tabular}{llllll}
\hline $\begin{array}{l}\text { Varyansın } \\
\text { Kaynağı }\end{array}$ & $\begin{array}{l}\text { Kareler } \\
\text { Toplamı }\end{array}$ & sd & $\begin{array}{l}\text { Kareler } \\
\text { Ortalaması }\end{array}$ & F & p \\
\hline Öntest reg. & 1258.044 & 1 & 1258.044 & 33.250 & .000 \\
& & & & & \\
Grup & 486.769 & 1 & 486.769 & 12.865 & .001 \\
Hata & 2080.990 & 55 & 37.836 & & \\
Toplam & 222730.000 & 58 & & & \\
\hline
\end{tabular}

Tablo 8. Fen ve Teknoloji Tutum Ölçeği Puanlarının Betimsel İstatistikleri

\begin{tabular}{llll}
\hline \multirow{3}{*}{ Grup } & N & \multicolumn{2}{c}{ Başarı-son test } \\
\cline { 3 - 3 } & & Ortalama & $\begin{array}{l}\text { Düzeltilmiş } \\
\text { Ortalama }\end{array}$ \\
\hline
\end{tabular}




\begin{tabular}{llll}
\hline Deney & 29 & 65.2759 & 64.335 \\
Kontrol & 29 & 57.4828 & 58.424 \\
\hline
\end{tabular}

Tablo 7 'deki analiz sonuçları incelendiğinde, gruplar arasında anlamlı bir farklılık olduğu görülmektedir $[\mathrm{F}(1)=12.865, \mathrm{p}<.05]$. Tablo 8 'deki tutum ön test puanlarına göre düzeltilmiş tutum son test puanları incelendiğinde de deney grubundaki öğrencilerin tutum puanlarının ortalamasının $(\bar{X}=64.335)$, kontrol grubundaki öğrencilerin tutum puanlarının ortalamasına göre $(\bar{X}=58.424)$ daha yüksek olduğu görülmektedir. Bu bulgular deney grubundaki öğrencilerin tutumlarının kontrol grubundaki öğrencilere göre daha olumlu olduğu şeklinde yorumlanabilir.

Analiz sonuçları incelendiğinde, öğrencilerin ön test-son test başarı değişimlerinin deney $[\mathrm{t}(28)=15.09, \mathrm{p}<.05]$ ve kontrol $[\mathrm{t}(28)=8.981, \mathrm{p}<.05]$ gruplarında son test puanlar1 lehine anlamlı farklılık gösterdiği görülmektedir. Bu bulgu, deneysel işlemlerin ve geleneksel işlenen dersin öğrenme üzerinde etkili olduğu biçiminde yorumlanabilir. Bununla birlikte Tablo 2 ve Tablo 3'deki analiz sonuçları birlikte yorumlandığında derse destek olarak kullanılan programlı öğretimin öğrenme açısından geleneksel öğretime göre daha etkili olduğu söylenebilir.

Tutum puanları ile ilgili olan analiz sonuçları incelendiğinde ise, deney grubundaki öğrencilerin programlı öğretim sonrasında fen ve teknoloji dersine yönelik tutumlarında anlamlı bir artış olduğu görülmektedir $[\mathrm{t}(28)=3.378, \mathrm{p}<.05]$. Kontrol grubundaki öğrencilerin ise geleneksel öğretim sonrasında fen ve teknoloji dersine yönelik tutumları arasında farklılık görülmemektedir $[\mathrm{t}(28)=.706, \mathrm{p}>.05]$. Bu bulgu, Tablo 2 ve Tablo 7'deki analiz sonuçları ile birlikte yorumlandığında programlı öğretimin öğrencilerin tutumlarını olumlu olarak artırdığı, geleneksel öğretimin ise öğrencilerin tutumlarını değiştirmediği şeklinde yorumlanabilir.

\section{Sonuçlar}

Fen öğretiminde programlı öğretimin öğrenci başarısı ve tutumu üzerindeki etkililiğini test etmeye yönelik deneysel nitelikteki bu araştırmada elde edilen bulgular ışığında su sonuçlara varılmıştır. Fen öğretiminde derse destek olarak uygulanan programlı öğretim geleneksel öğretime göre öğrenci başarısını anlamlı olarak artırmaktadır. Başka bir deyişle, 
fen öğretiminde derse destek olarak kullanılan programlı öğretim yöntemi geleneksel öğretim yönteminden daha etkilidir. Fen öğretiminde derse destek olarak uygulanan programlı öğretim geleneksel öğretime göre öğrenci tutumunu anlamlı olarak artırmaktadır. Yani, fen öğretiminde derse destek biçiminde programlı öğretim yöntemiyle ders isleyen öğrencilerin tutumları, geleneksel öğretim yöntemiyle ders isleyen öğrencilerin tutumlarından daha yüksektir. Ayrıca, deney grubundaki öğrencilerle programlı öğretim materyali hakkında yapılan görüşmelerde, öğrencilerin bu materyalleri kullanmaktan memnun olduklarını belirtmeleri, programlı öğretimin öğrencilerin tutumu üzerindeki etkisinin olumlu olduğunu göstermektedir.

\section{Tartışma}

Araştırma fen öğretiminde programlı öğretimin öğrenci başarısı ve tutumu üzerindeki etkisini incelemek amacıyla yapılmıştır. Araştırmada elde edilen sonuçlara göre, fen öğretiminde derse destek olarak uygulanan programlı öğretim geleneksel öğretime göre öğrenci başarısını ve tutumunu anlamlı olarak artırmaktadır. Yani, fen öğretiminde derse destek olarak kullanılan programlı öğretim yöntemiyle ders isleyen öğrencilerin başarı ve tutumları geleneksel öğretim yöntemiyle ders işleyen öğrencilerin başarı ve tutumlarından daha yüksektir. Elde edilen bu sonuç Çatalbaş’ın (1999 sy. 6) elde ettiği “Bulgular programlı öğretim yönteminin geleneksel öğretim yöntemine göre başarıyı olumlu yönde etkileyebileceği görüşünü destekler niteliktedir.”, Hızal'ın (1978, sy. 7) elde ettiği “programlı öğretim yöntemiyle ders gören deneme grubundaki denekler, öğretmen yönetiminde geleneksel yöntemle ders gören deneklerden daha başarılı olmuşlardır.”, Uz'un (2009) elde ettiği "Programlı Öğretim” yönteminin esas alındiğg deney 1 grubu öğrencilerinin, “işbirlikli Öğrenme” yöntemi “Öğrenci Takımları Başarı Bölümleri” tekniğinin esas alındiğı deney 2 grubu öğrencilerinden daha başarllı olduğu sonucuna ulaşılmıştır." sonuçlarıyla benzerlik göstermekteyken Sözen'in (2010, sy. 101) elde ettiği “programlı öğretim yöntemine göre düzenlenen deney etkinliklerin başarıyı arttırmadığı" sonucuyla benzerlik göstermemektedir.

Araştırma sonucunda geliştirilebilecek önerileri de şu şekilde sıralanabilir.

1. Özellikle yapılandırmacı kurama ve bu kuramdaki etkinlik kuramına göre tasarımlanan yeni ilköğretim programlarının daha etkili olabilmesi için, dersle birlikte öğrencilerin zamandan ve ortamdan bağımsız olarak kullanabilecekleri, kuvvet ve hareket konusuyla ilgili programlı öğretim materyalleri geliştirilmelidir. 
2. Programlı öğretimin öğrenci başarısı ve tutumu üzerindeki etkisinin yanı sıra; fen öğretiminde veya diğer disiplin alanlarında programlı öğretim modellerinden hangisinin öğrenme açısından daha etkili olacağı araştırılabilir.

3. Üniversite seçme sınavına veya ortaöğretim kurumlarına giriş sınavlarına hazırlanan öğrencilere sunulan kitaplar programlı öğretim ilkelerine uygun olarak hazırlanarak, varsa yayarları incelenebilir.

4. Uzaktan eğitim gören öğrencilerin kitap, cd, video vb. öğretim materyalleri programl materyalleri seklinde düzenlenebilir.

\section{Kaynaklar}

Alkan, C. (1977). Eğitim Teknolojisi. Yargıçoğlu Matbaası, s: 245-282, Ankara.

Büyükkaragöz, S. S., ve Çivi C. (1999). Genel Öğretim Metotları. Özel Eğitim Yayınları, İstanbul.

Büyüköztürk, Ş. (2004). Veri Analizi El Kitabı. PagemA Yayıncılık, s: 105, Ankara.

Çatalbaş, G., "Sosyal Bilgiler Öğretiminde Programlı Öğretim Yöntemi Uygulaması" 4.Ulusal Sınıf Öğretmenliği Sempozyumu 15-16 Ekim 1998 Pamukkale Üniversitesi Denizli Paü Eğitim Fakültesi Dergisi, Sayı:6 (Özel Sayı), 1999.

Çepni, S., Ayvacı, Ş. H., ve Bacanak, A. (2004). Fen Teknoloji Toplum. Top-Kar Matbaacılık, s:40, Trabzon.

Çilenti, K. (1979). Eğitim Teknolojisi: Kuramlar-Amaç ve Yöntemler-Merkezler. Kadığlu Matbaas1, Ankara.

Doğru, M., ve Kıyıcı, F., B. (2005). Fen Eğitiminin Zorluğu, Illköğretimde Fen ve Teknoloji Öğretimi. Aydoğdu, M., Kesercioğlu, T., Edit. Anı Yayıncılık, s: 5, Ankara.

Fidan, N., Baykul, Y. (1993). Illkokul ve İlköğretim Okullarında Temel Öğrenme İhtiyaçlarının Karşılanması. MEB Yayınları, s: 32-33, Ankara.

Geban, Ö., Ertepınar, H., Yılmaz, G., Altın, A., ve Şahbaz, F. (1994). "Bilgisayar Destekli Eğitimin Öğrencilerin Fen Bilgisi Başarılarına ve Fen Bilgisi İlgilerine Etkisi”. Birinci 
Ulusal Fen Bilimleri Eğitimi Sempozyumu Bildiri Özetleri Kitabı, Dokuz Eylül Üniversitesi, İzmir.

Hızal, A. (1978). "Programlı Öğretim Yönteminin Etkenliği ile İlgili Uygulamalı Bir Araştırma”. Eğitim ve Bilim. Sayı 17, s: 5-18.

Kurbanoğlu, N. İ. (2002). “Organik Kimyada Stereokimya Konusunun Programl Öğretimi”.V.Ulusal Fen Bilimleri ve Matematik Eğitimi Kongresi, s:646-650,Ankara.

Küçükahmet, L. (1997). Eğitim Programları ve Öğretim. Gazi Kitabevi, s:118-129, Ankara.

Küçükahmet, L. ( 1997). Öğretim İlke ve Yöntemleri, Gazi Kitabevi, sf. 114-128, Ankara.

Sözen, K. (2010). Sorgulayıcı Öğrenme Ve Programlı Öğretim Yöntemlerine Göre Işslenen Biyoloji Laboratuvarı Uygulamalarının Karşılaştırılması. Yüksek Lisans Tezi, Sakarya Üniversitesi.

Toplu B., Arslan A., Okumuş E., ve Akgün Ö. E. (2007). "Programlı Öğretim Uygulamalarının İlköğretim 7. Sınıf Öğrencilerinin Fen Bilgisi Dersi Başarı ve Tutumları Üzerindeki Etkisi Karşılaştırmalı Bir Araştırma”. Ulusal Teknik Eğitim Mühendislik ve Eğitim Bilimleri Genç Araştırmacılar Sempozyumu, s:993-996, Kocaeli.

Uz, Ö. (2009). Programlı Öğretim İle İşbirlikli Öğrenme Yaklaşımının 7. Sınıf Öğrencilerinin Akademik Başarısı ve Fen Tutumuna Etkisi. Yüksek Lisans Tezi, Sakarya Üniversitesi. 


\section{Ekler}

Ek-1. Programlı Materyal Örnĕgi

\section{Sevgili Öğrenciler;}

$\mathrm{Bu}$ kitapçık programlı öğretim yöntemine göre hazırlanmış bir öğretim materyalidir. $\mathrm{Bu}$ kitapçıkta "6. sınıf Kuvvet ve Hareket" konusu anlatılmaktadır. Kitapçıktaki her sayfada ekran adını verdiğimiz çerçeveler yer almaktadır. Her bir ekranda bilgi içeriği veya örnek veya soru bulunmaktadır. Ekranların altında ise ekran numaraları yer almaktadır. Kitapçığın sol tarafında ise soruların cevapları ve soruların cevaplarına göre, ne yapmanız gerektiğini bildiren yönergeler yer almaktadır.

Buna göre aşağıdaki işlem basamaklarını takip ediniz.

1) Verilen kartları cevaplar bölümünün üzerine kapatınız ve sağ taraftaki ekranları okumadan açmayınız.

2) Bilgi içeriğinin bulunduğu ekranları dikkatle okuyunuz.

3) Ardından örneklerin bulunduğu ekrana geçiniz.

4) Örnekleri inceledikten sonra sorunun bulunduğu ekrana geçiniz.

5) Sorunun cevabını çözdükten sonra, cevabı cevaplar bölümünden kontrol ediniz.

6) Eğer cevabınız doğruysa; bir sonraki ekrana geçiniz veya size bildirilen ekrana geçiniz.

7) Eğer cevabınız yanlışsa; size bildirilen ekrana geri döndükten sonra, soruyu tekrar çözmeyi deneyiniz.

8) Bir ekrandaki bilgileri tamamen okumadan diğer ekranlara geçmeyiniz. 


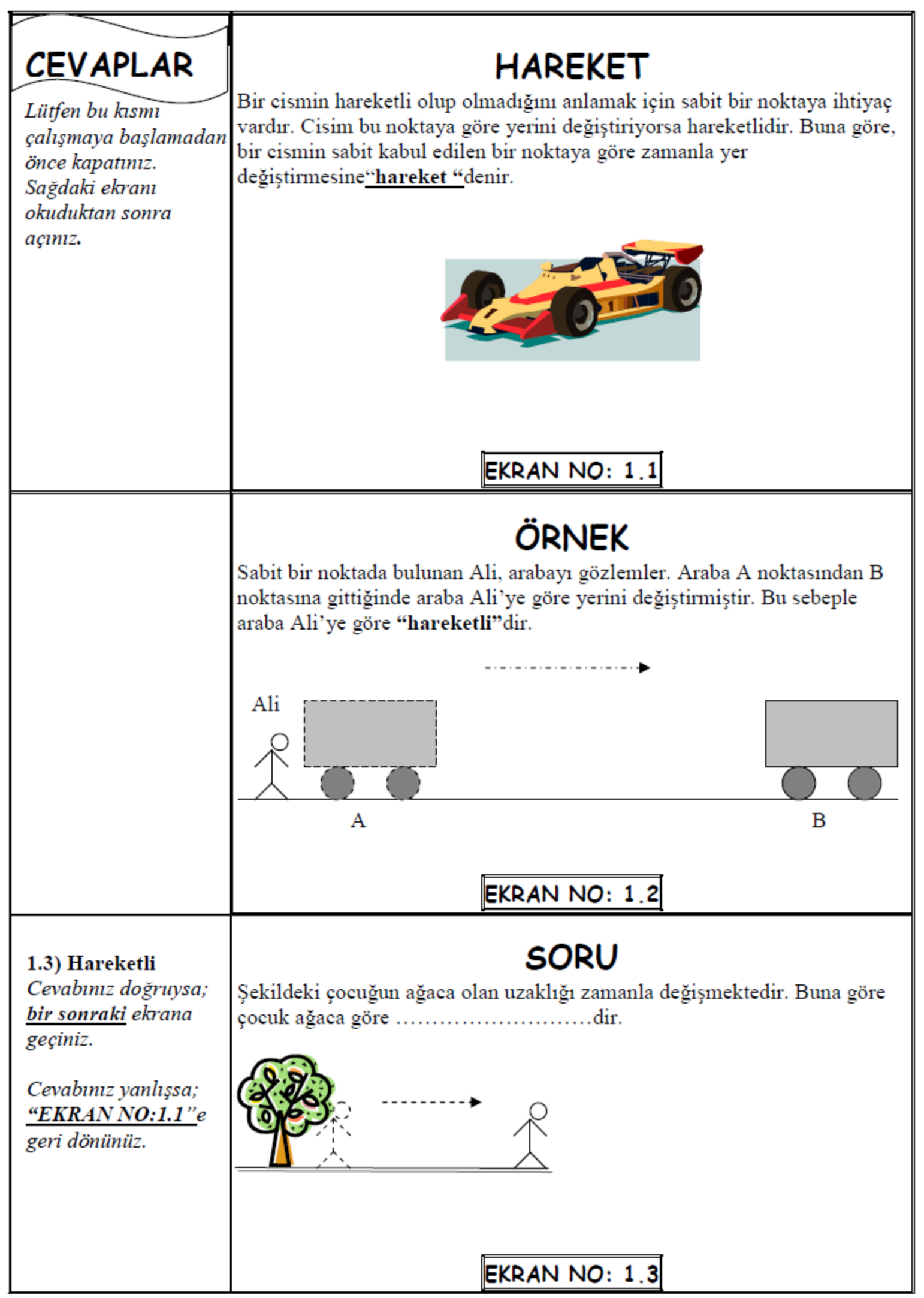

